\title{
CHEMICAL AND BIOLOGICAL STUdIES ON LEMONGRASS LEAVES Against Nephrotoxicity in Male RATS
}

\author{
By \\ Shimaa F.A.E. Ghozy \\ Home Economics Dept., \\ Faculty of Specific Education, \\ Mansoura University, Egypt \\ Awad, Nanees $Y, A$ \\ Home Economics Dept., \\ Faculty of Specific Education, \\ Mansoura University, Egypt
}

Research gournal Specific Fducation

Faculty of Specific Education

Mansoura University

ISSUE NO. 56, OCTOBER, 2019

مجلة بحوث التربية النوعية - جامعة المنصورة

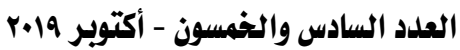


- Chemical and Biological Studies on Lemongrass Leaves Against Nephrotoxicity in Male Rats 


\title{
Chemical and BIOLOGICAL StUdies ON LeMONGRASS Leaves Against NePHROTOXICITY IN MALE RATS
}

\author{
Shimaa F.A.E. Ghozy* Awad, Nanees $Y, A^{* *}$
}

\section{Abstract}

The effect of different levels $(10,20 \& 30 \%)$ of lemongrass dry leaves (LEMS ) on renal dysfunction rats were evaluated . Thirty six male albino rats $150 \pm 5 \mathrm{~g}$ were used in this study and divided into 6 groups $(\mathrm{n}=6)$. Rats injected with $100 \mathrm{mg} / \mathrm{kg}$ b.wt gentamicin intraperitoneally daily to induce nephrotoxicity.

The results indicated that the protective groups rats fed on LEMS levels at $(10,20 \& 30 \%)$ diets showed significant higher in feed intake (FI), body weight gain (BWG), body weight $\%$, total protein, high density lipoprotein cholesterol (HDL-c), total antioxidants and SOD, Whereas showed significantly lower of alkaline phosphatase , albumin, uric acid, urea nitrogen , creatinine, total cholesterol (TC), triglyceride (TG), low density lipoprotein cholesterol (LDL-c), very low density lipoprotein cholesterol (VLDL-c) and tumor necrosis factor (TNF- $\alpha$ ) as compared to positive control group. The protective group at level 30\% LEMS recorded and drug group with ( $\alpha$ LA) the highest values of all parameters between all tested diets. Therefore, it can be concluded that the consumption of LEMS as food supplement may be considered a functional food for delay or protect risk of renal dysfunction. We suggest that the anti-inflammatory and antioxidant properties of GM were dependent on the total phenolics and flavonoid contents of the LEMS.

Key words:- Nephrotoxicity, a LA, lemongrass, Gallic acid equivalents, Catechin equivalents.

\footnotetext{
* Home Economics Dept., Faculty of Specific Education, Mansoura University, Egypt.

**Home Economics Dept., Faculty of Specific Education, Mansoura University, Egypt.
} 
- Chemical and Biological Studies on Lemongrass Leaves Against Nephrotoxicity in Male Rats

\section{INTRODUCTION}

The most prevalent causes of diabetes mellitus are diabetic nephropathy, high blood pressure, and nephritis. Jointly this causes approximately $75 \%$ of all adult status. Also certain geographic areas have a high rate of HIV.

Lemongrass (Cymbopogon schoenanthus L.) is native to Cambodia, Vietnam, India, Sri Lanka, Burma, South \& Southeast Asia. Lemongrass herb is using in Asian cuisines and medicinal herb in India (Tchamgoue and Kemeta 2012 and Akande et al., 2014). From a nutritional point of view, Lemongrass have interesting characteristics, as it has been supported by other studies on the chemical composition content of fiber, fat and fatty acids, protein, ash, vitamins and minerals (Mohammed, 2015).

The most important components in the lemongrass is known to be phenolic compounds such as caffeic acid, rosmarinic acid, metrilic acid, cholinergic acid, citral oil, C-glycosylflavones, orientin, isoorientin, chlorogenic acid and flavonoids like luteolin7-oxide-glucoside, apigenin and monoterpene derivatives such as beta-caryophyllene, germacrene, oleanolic, volatile oil, and tannins (Surinder, et al., 2010; Rabha, et al., 2012 and Nuntiya, 2018). Furthermore a study by Rahim et al., (2016) reported that supplementation of lemongrass is to athletes can increase total antioxidant capacity and prevent the enhancement of malondialdehyed level.

Gentamicin is antimicrobial representative of the amyglobulosides isolated from micromonospora porpora. Gentamicin is used to treat inflammation such as pneumonia, gallbladder, kidney, acute oocyte, and prostate (Tchoumbougnang, et al., 2015). The most important side effects of poisoning are kidney toxicity, magnesium deficiency in the blood, colitis, gastritis, nausea, vomiting, rashes and blood disorders (Moulds and Jeyasingham, 2012 and Emma, et al., 2016). 


\section{MATERIALS AND METHODS}

\section{MATERIALS}

Gentamicin ${ }^{\circledR}$ : was obtained from Memphis Company for Pharmaceutical and Chemical Imdustries ,Cairo, Egypt.

Alpha lipoic acid: $\alpha$-lipoic acid ${ }^{\odot}$ was an organosulfur compound derived from octanoic acid, purchased from El-Gomhoria Company. Cairo, Egypt.

Lemongrass (Cymbopogon Citratus) dry leaves: were obtained from the International Herbals Company, Cairo Egypt.

\section{Animals:}

35 male albino rats of Sprague Dawley strain weighing $150 \pm 5 \mathrm{~g}$ and 9:11 weeks aged were purchased from Laboratory of Animal Colony Helwan Egypt. Rats were maintained under controlled hygienic conditions. Animal were housed in clean cages, kept under controlled hygienic and maintained at room temperature at $25{ }^{\circ} \mathrm{C}$, relative humidity of $50 \pm 5$. Animals were fed on basal diet and water was provided ad libitum for 7 days before starting of the experiment.

\section{METHODS}

\section{Chemical analyses:}

Lemongrass dry leaves (moisture, proteins, fat, carbohydrates and ash) were analyzed for chemical composition using the procedures described by (A.O.A.C.2000). Total phenolics of lemongrass dry leaves were expressed as $\mathrm{mg}$ of gallic acid equivalents (GAE) per $\mathrm{g}$ of sample. Total flavonoids of lemongrass dry leaves were the results expressed as $\mathrm{mg}$ of (+)-catechin equivalents (CE) per $\mathrm{g}$ of sample determined by (Singleton et al., 1999 and Jia et al., 1999).

\section{Elaboration of the basal diet:}

Basal diet was prepared according to (Reeves et al., 1993) consists of $20 \%$ casein, $10 \%$ sucrose, $4 \%$ corn oil, $0.2 \%$ chlorine chloride, $1 \%$ vitamin mixture, $3.5 \%$ salt mixture,5\% fibers (cellulose) and the remainder was corn starch up to $100 \%$ 
- Chemical and Biological Studies on Lemongrass Leaves Against Nephrotoxicity in Male Rats

\section{Induction of nephrotoxicity.}

Rats injected with $100 \mathrm{mg} / \mathrm{kg}$ b.wt gentamicin intraperitoneally in the $4^{\text {th }}$ week daily till the end of the experiment for inducing nephrotoxicity according to (Farombi and Ekor 2006).

\section{Experimental design:}

36 adult Sprague dawley rats weighted $150 \pm 5 \mathrm{~g}$ the experiment on basal diet, then divided into two main groups, the first group ( $n=6$ rats) was fed on the basal diet only as a negative control $(\mathrm{C}-\mathrm{ve})$ normal rats. The rats of second main group ( $\mathrm{n}=30$ rats $)$ were injected by injected intraperitoneally (i.p.) with gentamicin GM $(100 \mathrm{mg} / \mathrm{kg})$, then divided into 4 sub-groups (each 6 rats) as follows:

Sub-group (2): Injected rats by GM were fed on basal diet as a positive control $(\mathrm{C}+\mathrm{ve})$.

Sub-group (3): Injected rats by GM were fed on basal diet and injected with alpha lipoic acid ( $\alpha$ LA) (35 mg/kg B.W daily) according to Thirunavukkarasu and Anuradha, (2004),

Sub-group (4), (5) \& (6): (18 rats) obtained the same composition as positive control diet in addition levels LEMS enhanced with $10 \%, 20 \%$ \& 30 LEMS.

For 4 week along with GM during the last week of the experiment. Feed intake was calculated daily and body weight gain was recorded weekly. At the end of the feeding period, the rats were euthanized by prolonged exposure to ether and blood samples were withdrawn for separating were kept frozen at $-70 \dot{C}$ till biochemical analyses. Rats were preparing tissue homogenates for biochemical analyses.

\section{Kidneys function marker:}

Serum urea, uric acid and creatinine were evaluated according to the method of (Patton and Crouch, 1977 and Jaffe, 1980).

\section{Liver function enzymes:}

Serum alanine and aspartate aminotransferases (ALT \& AST), alkaline phosphatase (ALP) enzymes activity, total bilirubin and serum total 
protein were performed by kinetic method according to (Reitman and Frankel, 1957, Persijn, et al., 1976 and Doumas, et al., 1975) respectively.

\section{Estimation of kidney antioxidant enzymes :}

Tissue superoxide dismutase (SOD) activity, total antioxidants capacity (TAC), and tumor necrosis factor (TNF- $\alpha$ ) were determined according to (Nishikimi, et al., 1972, Ohkawa, et al., 1979 and Thorell and Lanner, 1973) respectively.

\section{Statistical analysis:}

The obtained data were statistically analyzed using computerized SPSS (Statistic Program Sigmastat, Statistical Soft-Ware, SAS Institute, Cary, NC) (Snedecor and Cochran, 1967).

\section{RESULS AND DISCUSSION}

The chemical composition of lemongrass dry leaves (\%) was illustrated in Table (1). The results showed that, The content of moisture, protein, fat, ash and carbohydrate were 8.86, 10.12, 4.19, 6.21 and $70.62 \mathrm{~g} /$ $100 \mathrm{~g}$ respectively. These results are in agree with the data obtained by Hanaa, (2013) and Pedroso, et al., (2018) who found that, moisture, fat, protein, , ash and carbohydrate contents of different types of fresh mushroom were ranged 7.56, 9.73, 4.01, 5.87 and $72.84 \mathrm{~g} / 100 \mathrm{~g}$ respectively.

The T. phenol and flavonoids contents of lemongrass dry leaves were presented in table (4). The T. polyphenols and flavonoids contents of lemongrass were 138.59 (mg GAE/g) and 16.94 (mg CE/g). Lemongrass leaves was contain of antioxidant phytochemicals including flavonoids, phenolic acids, vitamins, fatty acids, trace elements (Hanaa, 2013 and Nuntiya, 2018). Additionally the phenolic acid content of, rosmarinic acid, cholinergic acid, c-glycosylflavones, orientin, isoorientin, chlorogenic acid and caffeic acid (Rabha, et al., 2012). Also, Rahim et al., (2016) recommended that, lemongrass contain of the bioactive compounds that move a part in the redate of the risk for the expansion of chronic diseases. 
The nephroprotective of treated fed on lemongrass dry leaves and with ( $\alpha$ LA) drug and in combination, against gentamicin GM induce nephrotoxicity in rats were investigated. Data presented in table (3) showed that significant decrease in the mean value of food intake as well as body weight gain $\%$ of $(\mathrm{C}+\mathrm{ve})$ group compared to $(\mathrm{C}-\mathrm{ve})$ group. Protective groups $(10,20$ and $30 \%$ LEMS $)$ and drug group with $(\alpha$ LA) had the highest values of food intake compared with the $(\mathrm{C}+\mathrm{ve})$ group. These results are in agreement with Reis, (2012) and Patel, et al., (2103) reduction in body weight gain probably GM produced renal failure that resulted in acidosis associated with loss of appetite for food caused by the drug which led to decrease in feed intake therefore cause lowest body weight.

Body weight gain $\%$ of the $(\mathrm{C}+\mathrm{ve})$ group was significantly decreased as compared with the $(\mathrm{C}-\mathrm{ve})$ group. The data showed that nonsignificant in body weight gain all other group protective groups levels (10, 20 and $30 \%$ LEMS) and drug group with ( $\alpha$ LA). On the other side, protective groups in chronic renal rats with $30 \%$ LEMS showed that the significant increase in body weight gain. These data are similar to the study of Rabha, et al., (2012) and Nuntiya, (2018) reported that LEMS a powerful antioxidant activity and a weight hight effect in rats.

The obtained results in table (4) illustrated that $(\mathrm{C}+\mathrm{ve})$ group showed that highest significantly in TC, TG, LDL-c, and VLDL-c, were showed lowest significantly in HDL-c in comparing with (C -ve) group. Protective groups levels (10, 20 and $30 \%$ LEMS) and drug group with $(\alpha$ LA) were recorded highest significantly in TC, TG, LDL-c and VLDL-c and showed lowest significantly in HDL-c in comparing with normal control group while showed lowest significantly in these previous parameters and highest significantly in HDL-c compare with $(\mathrm{C}+\mathrm{ve})$ group. The results are in agreement with (Hanaa, 2013 and Nuntiya, 2018) they reported that LEMS at a different at levels caused significant decreases in serum triglyceride, total cholesterol, LDL-cholesterol levels supposedly the presence of sterols in plants inhibits the body's absorption of cholesterol. Using a 30\% concentration of LEMS indicates significant reduction in the 
total plasma protein level, lipid profile and glucose levels, without a reduction in high density lipoproteins (HDLc) in rats.

The results in Table (5) serum liver parameters of rats groups were indicated that $(\mathrm{C}+\mathrm{ve})$ group recorded highest significantly in AST, ALT , ALP, T. bilirubin and $\mathrm{T}$. protein levels in comparing to $(\mathrm{C}-\mathrm{ve})$ group. Protective groups levels (10, 20 and $30 \%$ LEMS) and drug group with ( $\alpha$ LA) were significantly higher in AST, ALT, ALP. T. bilirubin and T. protein levels in comparing to $(\mathrm{C}-\mathrm{ve})$ group but showed significantly lower of these parameters in compared with positive control group. The decrease in serum ALT and AST in all rats fed on LEMS may be caused rich contained in polyphenols (Mohammed, 2015) Furthermore Nuntiya, (2018) indicated that, protective group with LEMS at level 30\% drug group $(\alpha$ LA) resulted in significant decrease in serum ALT and AST. Thence, the reduction in serum levels of AST, ALT, and ALP by lemongrass leaves therapy is an indication of establishing of plasma membrane as well as repair in tissue of hepatic. This effect shows that return to normal with the healing of hepatocytes may be to their qualitative phytochemical analysis which shows the presence of flavonoids in LEMS in Table (2).

The obtained results in Table (6) illustrated that $(\mathrm{C}+\mathrm{ve})$ group recorded highest significantly in uric acid, urea nitrogen and creatinine in comparison of $(\mathrm{C}-\mathrm{ve})$ group. While protective groups levels (10, 20 and 30 $\%$ LEMS) and drug group with ( $\alpha$ LA) were showed significantly higher in uric acid, urea nitrogen and creatinine in compared with (C -ve) group but showed significantly lower of these parameters in compared with $(\mathrm{C}+\mathrm{ve})$ group. GM activates the platelets activation factor causing local vasoconstriction and thus restricts the renal blood flow and ultimately glomerulus filtration rate (Polat, et al., 2006) The data were in the line with those of Pedroso, et al., (2018) and Nuntiya, (2018) cleared that all groups were fed on LEMS a good sources from dietary fiber had contained antioxidant have been suggested to have a role in protection against diseases cause that improved in the serum uric acid, urea nitrogen and creatinine levels, in all protective groups with LEMS at 30\% and drug group ( $\alpha$ LA) compared with the other groups of rats. 
Serum kidney antioxidant enzymes in rat groups in Table (7) approaches that $(\mathrm{C}+\mathrm{ve})$ group showed a significant lower in total antioxidants and SOD but showed a significant higher in TNF- $\alpha$ compared with (C -ve) group. The protective groups levels (10, 20 and $30 \%$ LEMS) and drug group with ( $\alpha$ LA) were showed a significant lower in total antioxidants and SOD but showed a significant increase in TNF- $\alpha$ compared with normal control group. While showed a significant increase in total antioxidants and SOD but showed a significant decrease in TNF- $\alpha$ compared with both that $(\mathrm{C}+\mathrm{ve})$ group. These results are in equivalent with those obtained by Pedroso, et al., (2018) who detected that natural antioxidants have a substantial role in prevent free radicals and oxidative series response at the tissue and membrane levels. LEMS was a good source in phenolic compounds may be anti-oxidant activity. Moreover, the addition of LEMS to the diet affected oxidative status by lowering levels of TNF- $\alpha$ and anti-oxidant enzyme activity in the body (Saeidnia, et al., (2004) and Nuntiya, (2018).

From these results we can conclude that the administration by GM has a negative effects, and the active components of LEMS and drug group with ( $\alpha$ LA) reflects an important role in the inhibition of these effects in different parameters that has been taken in consideration in this study. Their LEMS were rich with free radical scavenging molecules and it can be used as a potential source of natural antioxidants and nutrients. The use of it as a natural antioxidant source appears to be an alternative to synthetic antioxidants of renal dysfunction and nephrotoxicity.

Table (1): Chemical composition of lemongrass dry leaves (\%)

\begin{tabular}{||c|c|c|c|c|c||}
\hline \hline parameters & Moisture & Protein & Fat & Ash & Carbohydrate \\
\hline Lemongrass & 8.86 & 10.12 & 4.19 & 6.21 & 70.62 \\
\hline
\end{tabular}

Values are the means of 3 independent determinations. 


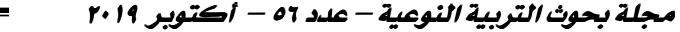

Table (2): Phytochemicals content of lemongrass dry leaves

\begin{tabular}{|c|c|c|}
\hline \multirow{2}{*}{ parameters } & T. polyphenols & T. flavonoids \\
\cline { 2 - 3 } & \multicolumn{2}{|c|}{ (mg GAE/g) } \\
\hline Lemongrass & 138.59 & 16.94 \\
\hline
\end{tabular}

GAE: Gallic acid equivalents CE: Catechin equivalents

Table (3): Effect of different levels of lemongrass leaves on body weight, feed intake and FRE in rat groups

\begin{tabular}{||c|c|c|c|c||}
\hline \multicolumn{2}{|c|}{ Parameters } & $\begin{array}{c}\text { Weight gain } \\
\text { Groups }\end{array}$ & $\begin{array}{c}\text { Feed intake } \\
(\mathbf{g})\end{array}$ & FER \\
\hline \hline \multicolumn{2}{|c|}{ Group (1): -ve } & $98.76 \pm 8.11 \mathrm{a}$ & $17.94 \pm 2.20 \mathrm{a}$ & $0.187 \pm 0.03 \mathrm{a}$ \\
\hline \multicolumn{2}{|c|}{ Group (2): +ve } & $20.64 \pm 8.11 \mathrm{~d}$ & $13.94 \pm 2.20 \mathrm{~d}$ & $0.67 \pm 0.06 \mathrm{e}$ \\
\hline \multicolumn{2}{|c|}{ Group (3): ( $\alpha$ LA) } & $97.59 \pm 6.11 \mathrm{a}$ & $17.80 \pm 2.03 \mathrm{a}$ & $0.182 \pm 0.02 \mathrm{~b}$ \\
\hline \multirow{2}{*}{$\begin{array}{c}\text { Protective } \\
\text { Group }\end{array}$} & Group (4) & $85.13 \pm 9.13 \mathrm{c}$ & $16.66 \pm 2.32 \mathrm{a}$ & $0.185 \pm 0.04 \mathrm{~b}$ \\
\cline { 2 - 6 } & Group (5) & $88.77 \pm 9.17 \mathrm{c}$ & $16.65 \pm 2.21 \mathrm{a}$ & $0.183 \pm 0.03 \mathrm{~b}$ \\
\cline { 2 - 6 } & Group (6) & $89.44 \pm 9.17 \mathrm{~b}$ & $16.68 \pm 2.92 \mathrm{a}$ & $0.185 \pm 0.04 \mathrm{ab}$ \\
\hline \hline
\end{tabular}

Values in the same column having different superscripts letters are significantly $(\mathrm{p}<0.05)$ different and vice versa..

Table (4): Effect of different levels of lemongrass leaves on serum lipid profile of rats groups

\begin{tabular}{|c|c|c|c|c|c|c|}
\hline \multirow{2}{*}{\multicolumn{2}{|c|}{ Groups }} & TC & TG & LDL-c & HDL-c & VLDL-c \\
\hline & & \multicolumn{5}{|c|}{$\mathrm{mg} / \mathrm{dl}$} \\
\hline \multicolumn{2}{|c|}{ Group (1): -ve } & $75.49 \pm 3.86 \mathrm{c}$ & $45.16 \pm 2.28 \mathrm{c}$ & $28.35 \pm 0.71 \mathrm{a}$ & $38.30 \pm 2.25 \mathrm{~d}$ & $9.03 \pm 0.457 \mathrm{c}$ \\
\hline \multicolumn{2}{|c|}{ Group (2): +ve } & $121.46 \pm 3.84 \mathrm{a}$ & $75.43 \pm 4.15 \mathrm{a}$ & $19.47 \pm 1.18 \mathrm{e}$ & $86.21 \pm 2.83 \mathrm{a}$ & $15.85 \pm 0.83 \mathrm{a}$ \\
\hline \multicolumn{2}{|c|}{ Group (3): } & $76.48 \pm 4.28 \mathrm{c}$ & $45.34 \pm 3.03 \mathrm{c}$ & $28.38 \pm 1.76 \mathrm{a}$ & $39.02 \pm 2.76 \mathrm{~d}$ & $9.09 \pm 0.61 \mathrm{c}$ \\
\hline \multirow{3}{*}{$\mid \begin{array}{c}\text { Protective } \\
\text { Group }\end{array}$} & Group (4) & $81.27 \pm 4.54 \mathrm{~b}$ & $51.19 \pm 3.46 \mathrm{~b}$ & $24.03 \pm 0.37 \mathrm{c}$ & $46.97 \pm 2.75 \mathrm{~b}$ & $10.29 \pm 0.62 \mathrm{~d}$ \\
\hline & Group (5) & $80.14 \pm 3.65 \mathrm{~b}$ & $49.18 \pm 2.795 \mathrm{~b}$ & $27.71 \pm 2.36 \mathrm{~b}$ & $42.60 \pm 1.74 \mathrm{c}$ & $9.83 \pm 0.59 b$ \\
\hline & Group (6) & $77.46 \pm 3.65 \mathrm{c}$ & $47.76 \pm 2.75 b$ & $26.92 \pm 2.36 \mathrm{~b}$ & $40.97 \pm 1.74 \mathrm{c}$ & $9.57 \pm 0.59 \mathrm{~b}$ \\
\hline
\end{tabular}

Values in the same column having different superscripts letters are significantly $(\mathrm{p}<0.05)$ different and vice versa. 
- Chemical and Biological Studies on Lemongrass Leaves Against Nephrotoxicity in Male Rats

Table (5): Effect of different levels of lemongrass leaves on serum liver parameters of rats groups

\begin{tabular}{|c|c|c|c|c|c|c|}
\hline \multicolumn{2}{|c|}{$\begin{array}{l}\text { Parameters } \\
\text { Groups }\end{array}$} & $\begin{array}{l}\text { AST } \\
(\mathbf{U} / \mathbf{L})\end{array}$ & $\begin{array}{l}\mathbf{A L T} \\
(\mathbf{U} / \mathbf{L})\end{array}$ & $\begin{array}{l}\text { ALP } \\
(\mathbf{I u} / \mathbf{l})\end{array}$ & $\begin{array}{c}\text { T. bilirubin } \\
\text { mg / dl }\end{array}$ & $\begin{array}{c}\text { T. protein } \\
\text { g / dl }\end{array}$ \\
\hline \multicolumn{2}{|c|}{ Group (1): -ve } & $\begin{array}{l}43.82 \pm \\
2.11 \mathrm{~d}\end{array}$ & $\begin{array}{r}22.51 \pm \\
1.78 \mathrm{~d}\end{array}$ & $\begin{array}{l}66.26 \pm \\
3.97 \mathrm{e}\end{array}$ & $\begin{array}{r}0.25 \\
\pm 0.06 \mathrm{e}\end{array}$ & $\begin{array}{r}8.69 \\
\pm 0.31 \mathrm{a}\end{array}$ \\
\hline \multicolumn{2}{|c|}{ Group (2): +ve } & $\begin{array}{r}84.07 \pm \\
5.58 \mathrm{a} \\
\end{array}$ & $\begin{array}{l}46.36 \pm \\
3.27 \mathrm{a} \\
\end{array}$ & $\begin{array}{c}114.39 \pm \\
6.49 \mathrm{a} \\
\end{array}$ & $\begin{array}{r}1.96 \\
\pm 0.18 \mathrm{a} \\
\end{array}$ & $\begin{array}{r}4.00 \\
\pm 0.36 \mathrm{c} \\
\end{array}$ \\
\hline \multicolumn{2}{|c|}{ Group (3): $\alpha$ LA } & $\begin{array}{r}42.86 \pm \\
2.75 \mathrm{~d} \\
\end{array}$ & $\begin{array}{l}22.46 \pm \\
2.13 \mathrm{~d}\end{array}$ & $\begin{array}{l}78.33 \pm \\
3.65 \mathrm{e} \\
\end{array}$ & $\begin{array}{r}0.43 \\
\pm 0.14 \mathrm{~d} \\
\end{array}$ & $\begin{array}{r}7.99 \\
\pm 0.21 \mathrm{a} \\
\end{array}$ \\
\hline \multirow[t]{3}{*}{$\begin{array}{c}\text { Protective } \\
\text { Group }\end{array}$} & Group (4) & $\begin{array}{l}50.08 \pm \\
4.28 \mathrm{~b} \\
\end{array}$ & $\begin{array}{c}27.99 \pm \\
3.43 \mathrm{~b} \\
\end{array}$ & $\begin{array}{l}96.764 \pm \\
5.649 \mathrm{~b} \\
\end{array}$ & $\begin{array}{r}0.51 \\
\pm 0.06 \mathrm{c} \\
\end{array}$ & $\begin{array}{r}5.93 \\
\pm 0.51 \mathrm{~b} \\
\end{array}$ \\
\hline & Group (5) & $\begin{array}{l}46.82 \pm \\
3.02 \mathrm{c} \\
\end{array}$ & $\begin{array}{c}26.73 \pm \\
2.14 \mathrm{~b} \\
\end{array}$ & $\begin{array}{l}92.896 \pm \\
2.622 \mathrm{~b} \\
\end{array}$ & $\begin{array}{r}0.31 \\
\pm 0.03 \mathrm{~d} \\
\end{array}$ & $\begin{array}{r}7.89 \\
\pm 0.36 \mathrm{a} \\
\end{array}$ \\
\hline & Group (6) & $\begin{array}{l}47.08 \pm \\
4.13 \mathrm{c}\end{array}$ & $\begin{array}{c}25.13 \pm \\
3.43 \mathrm{c} \\
\end{array}$ & $\begin{array}{l}90.896 \pm \\
2.622 \mathrm{~b}\end{array}$ & $\begin{array}{c}0.31 \\
\pm 0.03 \mathrm{~d}\end{array}$ & $\begin{array}{r}8.10 \\
\pm 0.36 \mathrm{a} \\
\end{array}$ \\
\hline
\end{tabular}

Values in the same column having different superscripts letters are significantly $(\mathrm{p}<0.05)$ different and vice versa.

AST: aspartate aminotransferase enzymes ALP: alkaline phosphatase

Table (6): Effect of different levels of lemongrass leaves on serum kidney parameters in rat groups

\begin{tabular}{|c|c|c|c|c|}
\hline \multirow{2}{*}{\multicolumn{2}{|c|}{$\begin{array}{l}\text { Parameters } \\
\text { Groups }\end{array}$}} & Uric acid & Creatinine & Urea Nitrogen \\
\hline & & \multicolumn{3}{|c|}{$\mathrm{mg} / \mathrm{dl}$} \\
\hline \multicolumn{2}{|c|}{ Group (1): -ve } & $1.51 \pm 0.42 \mathrm{~d}$ & $1.34 \pm 0.54 \mathrm{~d}$ & $35.99 \pm 2.91 d$ \\
\hline \multicolumn{2}{|c|}{ Group (2): +ve } & $2.99 \pm 0.62 \mathrm{a}$ & $3.91 \pm 0.47 \mathrm{a}$ & $62.96 \pm 3.57 \mathrm{a}$ \\
\hline \multicolumn{2}{|c|}{ Group (3): $\alpha$ LA } & $1.62 \pm 0.14 \mathrm{c}$ & $1.45 \pm 0.13 \mathrm{c}$ & $36.70 \pm 2.39 \mathrm{c}$ \\
\hline \multirow{4}{*}{$\begin{array}{c}\text { Protective } \\
\text { Group }\end{array}$} & Group (4) & $1.91 \pm 0.16 \mathrm{~b}$ & $2.07 \pm 0.17 \mathrm{~b}$ & $40.39 \pm 4.48 \mathrm{~b}$ \\
\hline & Group (5) & $1.84 \pm 0.80 \mathrm{~b}$ & $2.00 \pm 0.25 \mathrm{~b}$ & $40.21 \pm 3.38 \mathrm{~b}$ \\
\hline & Group (6) & $1.80 \pm 0.70 \mathrm{~b}$ & $1.83 \pm 0.25 \mathrm{c}$ & $37.76 \pm 3.38 \mathrm{c}$ \\
\hline & Group (7) & $1.75 \pm 0.60 \mathrm{~b}$ & $1.63 \pm 0.25 \mathrm{c}$ & $37.21 \pm 3.38 \mathrm{c}$ \\
\hline
\end{tabular}

Values in the same column having different superscripts letters are significantly $(\mathrm{p}<0.05)$ different and vice versa. 
Table (7): Effect of different levels of lemongrass leaves on serum kidney antioxidant enzymes in rat groups

\begin{tabular}{|c|c|c|c|c|}
\hline \multicolumn{2}{|c|}{ Groups } & $\begin{array}{l}\text { TNF- } \alpha \\
(\mathrm{pg} / \mathrm{ml})\end{array}$ & $\begin{array}{c}\text { Total antioxidants } \\
\mathrm{mmol} / \mathrm{L}\end{array}$ & $\begin{array}{c}\text { Superoxide dismutase } \\
\mathrm{U} / \mathrm{mL}\end{array}$ \\
\hline \multicolumn{2}{|c|}{ Group (1): -ve } & $4.1 \pm 0.09 \mathrm{~d}$ & $4.38 \pm 0.75 \mathrm{a}$ & $166.23 \pm 12.74$ a \\
\hline \multicolumn{2}{|c|}{ Group (2): +ve } & $9.8 \pm 0.16 \mathrm{a}$ & $1.17 \pm 0.55 \mathrm{~d}$ & $114.33 \pm 12.01 \mathrm{~d}$ \\
\hline \multicolumn{2}{|c|}{ Group (3): $\alpha$ LA } & $5.32 \pm 0.01 \mathrm{c}$ & $3.98 \pm 0.65 \mathrm{a}$ & $152.12 \pm 13.01$ a \\
\hline \multirow{3}{*}{$\begin{array}{c}\text { Protective } \\
\text { Group }\end{array}$} & Group (4) & $7.96 \pm 0.11 b$ & $2.58 \pm 0.80 \mathrm{~b}$ & $148.33 \pm 14.81 \mathrm{bc}$ \\
\hline & Group (5) & $6.11 \pm 0.10 \mathrm{~b}$ & $3.21 \pm 0.09 \mathrm{a}$ & $156.01 \pm 14.10 \mathrm{~b}$ \\
\hline & Group (6) & $5.71 \pm 0.12 c$ & $3.69 \pm 0.80 \mathrm{a}$ & $159.81 \pm 19.64 \mathrm{~b}$ \\
\hline
\end{tabular}

Values in the same column having different superscripts letters are significantly $(\mathrm{p}<0.05)$ different and vice versa.

\section{REFERENCES}

- A O A C., (2000): Association of Official Agricultural Chemists. Official Method of Analysis. 17th Ed. Vol. 11. Washington U.S. A.

- Cao, G., Sofic E. and Prior R. L.(1996): Antioxidant capacity of tea and common vegetables. J. Agric. Food Chem., 44:3426-3431.

- Doumas B.T., Ferry B.W., Sasse E.A. and Straum, J.V. (1973): Cited in the pamphlet of Quimica. Clinica. Aplicada Amposta. Spain. Clin. Chem.; 19; 984993.

- Doumas, T., Watson, W. and Biggs, H. (1975): Colourimetric determination of total protein in serum or plasma. Clin. Chem., 21 (8): 1159- 1166.

- Emma, Hathorn; Divya, Dhasmana; Lelia, Duley; and Jonathan, DC Ross (2016): The effectiveness of gentamicin in the treatment of Neisseria gonorrhoeae: a systematic review. Systematic Review. 3: 104.

- Farombi, E and Ekor, M. (2006): Curcumin attenuates gentamicin- induced renal oxidative damage in rats. Medicina, 44(9):1443-1448.

- Hanaa F. EL-Mehiry (2013): Hepatoprotective Effect of Lemongrass (Cymbopogon Citratus) Against Oxyteracycline -Induced Fatty Liver in Male Rats. The New Egyptian Jouranl Of Medicine 2(49):15-28, ISSN 1110-1946.

- Jaffe, M. (1980): Determination of creatinine in serum. Phys. Chem., 10: 391. 
- Chemical and Biological Studies on Lemongrass Leaves Against Nephrotoxicity in Male Rats

- Jia Zhishen, Tang Mengcheng, and Wu Jianming, (1999): The determination of flavonoid contents in Mulberry and their scavenging effects on superoxide radicals. Food Chemistry 64(4):555-559

- Mohammed Haggag, (2015): Protective effect of lemon grass (Cymbopogon citratus) water extract against nephrotoxicity induced by cisplatin of male rats. J. of Nutrition and Health. Egypt.10, (1), 1-12

- Moulds, Robert; and Jeyasingham, Melanie (2012): Gentamicin: a great way to start. Australian Prescriber (33): 134-135.

- Nishikimi, M., Rao N.A. and Yogi K. (1972): Colorimetric determination of superoxide dismutase in tissues. Biochem. Biophys. Res. Common.,46: 849854.

- Nuntiya Somparn, Suphaket Saenthaweeuk, and Jarinyaporn Naowaboot (2018): Effect of lemongrass water extract supplementation on atherogenic index and antioxidant status in rats. Acta Pharmaceutica 68(2):185-197

- Ohkawa, H., Ohishi, N., and Yagi, K. (1979): Assay for lipid peroxidation in animal tissues by thiobarbituric acid reaction. Annals of Biochemistry.,95:351358.

- Patel Manali, B., Deshpande, S. and Shah, G. (2011): Evaluation of efficacy of vitamin $\mathrm{E}$ and $\mathrm{N}$-acetyl cysteine in gentamicin-induced nephrotoxicity in rats. Ren Fail 33, 341-347

- Patton, C. and Crouch, S. (1977): A colorimetric method for the determination of blood urea concentration. J. Anal. Chem., 49:464-469.

- Pedroso, R. B., Ueda,Nakamura, T., Filho, B. P., Cortez, D. A. G., Cortez, L . E. R., Morgado-Díaz, J. A. and Nakamura, C. V. (2018): Biological activities of essential oil obtained from Cymbopogon citratus on Crithidia deanei. Acta Protozoologica 45, 231-240.

- Persijn, J., Slik, W. and Van, D. ( 1976 ): Clin. Chem. Biochem., 14: 421427.

- Rabha, B., Gopalkrishnan, R., Baruah, I. and Singh, L. (2012): Larvicidal activity of some essential oil hydrolates against dengue and filariasis vectors, Journal of Medical Research, 2012, 1 (1): 14-16.

- Rahim, S.M., Taha, E.M., Mubark, Z.M., Aziz, S.S., Simon, K.D. and Mazlan, A.G. (2016): Protective effect of Cymbopogon citratus on hydrogen peroxide-induced oxidative stress in the reproductive system of male rats. Syst Biol Reprod Med..82: 68 
- Reeves P.G., Nielson F.H. and Fahmy G.C.(1993): Reports of the American Institute of Nutrition, Adhoc Wiling Committee on reformulation of the AIN 93. Rodent Diet. J. Nutri.; 123: 1939-1951.

- Reis, L. A. (2012): Bone marrow-derived mesenchymal stem cells repaired but did not prevent gentamicin-induced acute kidney injury through paracrine effects in rats. PloS one 7, e44092.

- Reitman, S. and Frankel, S. (1957): Estimation of serum alanine and aspartate aminotransferases. Clin .Path. Am. J.; 28: 57-63.

- Saeidnia, S., Gohari, A. R., Uchiyama, N., Ito, M., Honda, G. and Kiuchi, F. (2004): Two new monoterpene glycosides and trypanocidal terpenoids from Dracocephalum kotschyi. Chemical and Pharmaceutical Bulletin (Tokyo) 52, 1249-1250.

- Singleton, V.L., Orthofer, R., Lamuela-Raventos, R.M. (1999): Analysis of total phenols and other oxidation substrates and antioxidants by means of FolinCiocalteu reagent. Methods Enzymol. 299, 152-178.

- Snedecor, G.W. and Cochran, W.G. (1967): Statistical Methods; $7^{\text {th }}$ Ed., The Iowa State University Press., Ames, Iowa, U.S.A.

- Surinder A., Balamurugan N., and Gunaseelan K. (2010): Adverse drug reaction profile of cisplatin based chemotheraby regimen in tertiary care hospital in India: An evaluation study, Indian J.Pharmaco1.42:40-43. Tarkang P.A., Agbor G.A., Tsabang N., Tchokouaha R.Y.,

- Tchamgoue D.A.and Kemeta D. (2012): Effect of long-term oral administration of the aqueous and ethanol leaf extract of cymbopogon citratus (DC. Ex Ness) Stapf. Ann Biol Res; 3:5561-5570.

- Tchoumbougnang F., Zollo P.H., Dagne E. and Mekonnen Y.(2005): In vivo anti malaria activity of essential oils from cymbopogon citratus and ocimum gratissimum on mice injected with Plasmodium Berghei. Planta Medica; 71:2023.

- Thirunavukkarasu, V. and Anuradha, C. (2004): Influence of alpha- lipoic acid on lipid peroxidation and antioxidant defence system in blood of insulinresistant rats. Diabetes Obes. Metab., 6(3):200-7.

- Thorell, J.I. and Lanner, A. (1973): Influence of heparin-plasma, EDTAplasma and serum on the determination of insulin with three different radioimmunoassay. Scand. J. Clin Lab. Invest., 31:187-190. 
- Chemical and Biological Studies on Lemongrass Leaves Against Nephrotoxicity in Male Rats

\section{دراسة كيميائية وبيولوجية على أوراق حشيشة الليشون ضد السميية الكلوية فى ذكور الفئران}

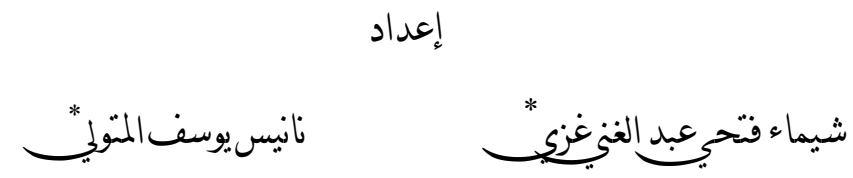

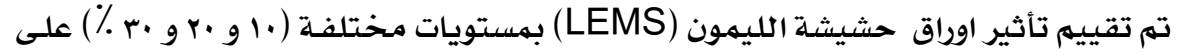

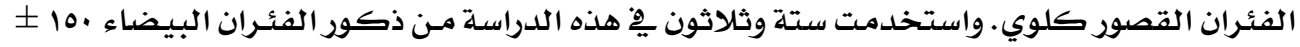

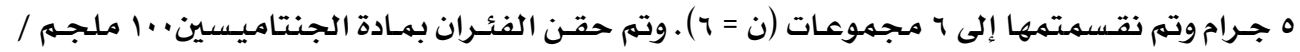

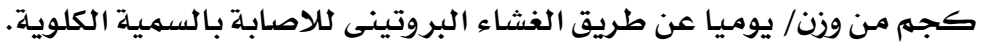

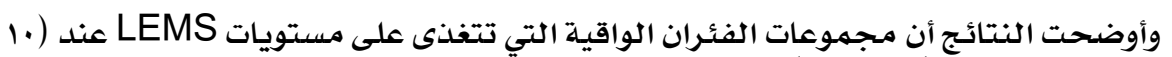

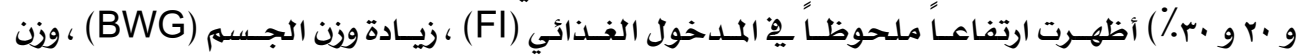

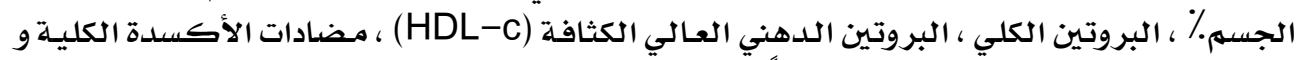

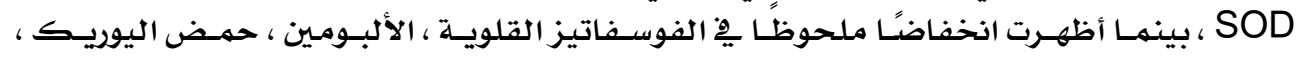

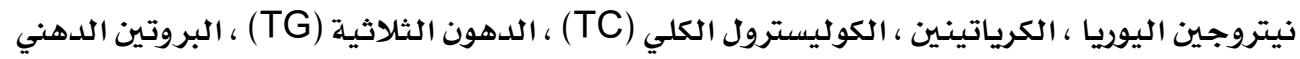

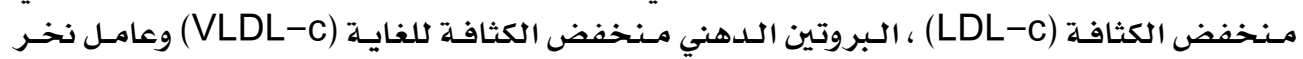

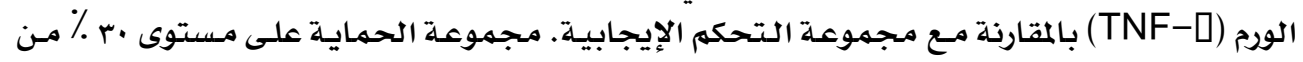

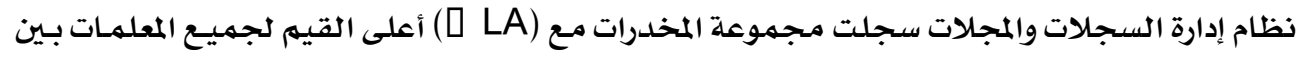

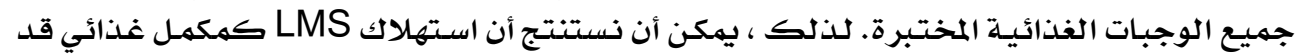

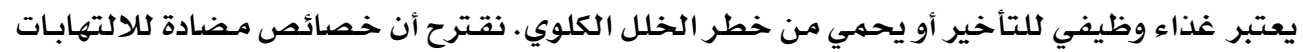

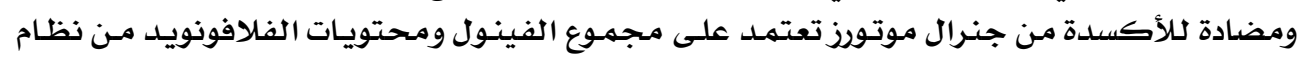

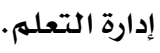

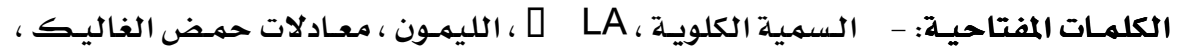

معادلات كاتشين.

قسم الاقتصاد المنزلي - كلية التربية النوعية- جـامعة المنصورة - مصر 